\title{
FAKTOR-FAKTOR PEMBENTUK LOYALITAS MEREK PADA PENGGUNA PONSEL SMARTFREN
}

\author{
Aji Wira Tama \& Wisnu Untoro \\ Universitas Sebelas Maret Surakarta, Indonesia \\ Email: ajiwiratama365@gmail.com
}

\begin{abstract}
Abstrak: Faktor-Faktor Pembentuk Loyalitas Merek pada Pengguna Ponsel Smartfren. Penelitian ini bertujuan menguji pengaruh dimensi dari nilai pelanggan dan identifikasi merek terhadap loyalitas merek dengan kepuasan pelanggan sebagai variabel mediasi. Penelitian ini menggunakan teknik purposive sampling dengan jumlah sampel sebanyak 175 responden pada pelanggan Smartfren. Hasil penelitian menunjukkan bahwa (1) nilai fungsional berpengaruh positif terhadap kepuasan pelanggan, (2) nilai emosional tidak berpengaruh terhadap kepuasan pelanggan, (3) nilai sosial tidak berpengaruh terhadap kepuasan pelanggan, (4) identifikasi merek berpengaruh positif terhadap kepuasan pelanggan, (5) nilai fungsional tidak berpengaruh terhadap loyalitas merek, (6) nilai emosional tidak berpengaruh terhadap loyalitas merek, (7) nilai sosial berpengaruh terhadap loyalitas merek, (8) identifikasi merek tidak berpengaruh terhadap loyalitas merek, (9) kepuasan pelanggan berpengaruh positif terhadap loyalitas merek, (10) nilai fungsional, nilai emosional, nilai sosial dan identifikasi merek tidak terbukti berpengaruh secara simultan terhadap loyalitas merek dengan kepuasan pelanggan sebagai variabel mediasi.
\end{abstract}

Kata kunci: Nilai pelanggan, identifikasi merek, kepuasan pelanggan, loyalitas merek

\begin{abstract}
Factors Affecting Brand Loyalty among Smartfren Customers. The purpose of this study was to analyze the effect of the dimensions of customer value and brand identification on brand loyalty and customer satisfaction as a mediating variable. A purposive sampling technique was adopted to collect 175 Smartfren customers. The results showed that: (1) the functional value has positive effect on customer satisfaction, (2) the emotional value has no effect on customer satisfaction, (3) social values has no effect on customer satisfaction, (4) brand identification has positive impact on customer satisfaction, (5) functional value has no effect on brand loyalty, (6) the emotional value has no effect on brand loyalty, (7) social value has positive effect on brand loyalty, (8) brand identification has no effect on brand loyalty, (9) customer satisfaction has positive effect on loyalty brand, (10) the functional value, emotional value, social value and brand identification simultaneous have no effect on brand loyalty with customer satisfaction as a mediating variable.
\end{abstract}

Keywords: Customer value, brand identification, customer satisfaction, brand loyalty

\section{PENDAHULUAN}

Peran dan tugas manajer pemasaran untuk menjaga pelanggan yang loyal menjadi sangat penting dengan munculnya merek merek produk yang bersaing di pasar kompetitif (Jones dan Sasser, 1995). Para peneliti menghabiskan banyak waktu untuk melakukan penelitian mengenai loyalitas merek. Loyalitas merek secara langsung dipengaruhi oleh kepuasan pelanggan terhadap merek produk tertentu. Seorang pelanggan jika merasa puas dengan nilai yang 
diberikan oleh produk atau jasa maka akan sangat besar kemungkinannya untuk menjadi pelanggan dalam waktu yang lama atau loyal (Umar, 2000:50).

Penelitian terdahulu meneliti tentang dua sudut pandang alasan terbentuknya loyalitas merek. Yang pertama adalah teori nilai pelanggan, yaitu persepsi nilai merupakan suatu prediktor penting dari loyalitas merek (Kim, Gupta dan Koh, 2011; Sweeney dan Soutar, 2001). Pelanggan akan tetap setia jika memberikan nilai yang tinggi terhadap suatu merek produk tertentu (Hansen, Beitelspacher dan Deitz, 2013). Sudut pandang kedua yaitu pendekatan identifikasi, yang menempatkan identifikasi pelanggan pada merek (selanjutnya disebut sebagai identifikasi merek) sebagai sebuah anteseden dari loyalitas merek (Bhattacharya dan Sen, 2003; Tu`skej, Golob dan Podnar, 2013). Beberapa penelitian lanjutan berpendapat bahwa kedua sudut pandang ini berpengaruh positif terhadap kepercayaan merek dan kemudian loyalitas merek (He, Li dan Harris, 2012).

Penelitian terdahulu mengungkapkan kesulitan manajer pemasaran menghadapi prediksi dari nilai pelanggan dan identifikasi merek tentang alokasi sumber daya karena dua sudut pandang yang berbeda. Strategi dari teori nilai pelanggan mendorong manajer untuk menekankan pengembangan produk dan mengkomunikasikan manfaat dari atribut produk tersebut kepada pelanggan (Karjaluoto, Jayawardhena, Leppäniemi, dan Pihlström, 2012). Sedangkan strategi identifikasi merek mendorong manajer untuk membuat identitas merek yang menarik dan menjalin hubungan merek dengan pelanggan lebih dekat dalam suatu komunitas masyarakat (Stokburger-Sauer, N., Ratneshwar, S., dan Sen, S., 2012). Sebagai manajer harus dapat membuat sinergi mengelola nilai pelanggan dan identifikasi merek oleh pelanggan yang dimediasi kepuasan sehingga berpengaruh terhadap loyalitas merek.

Sebuah fanpage Facebook adalah platform yang diprakarsai oleh merek, perusahaan atau individu untuk merilis berita, berinteraksi dengan penggemar dan mengumpulkan fans atau pengguna. Banyak perusahaan, seperti Starbucks, HTC, ASUS dan Mini Cooper telah memanfaatkan fanpage untuk melakukan pemasaran dan kegiatan iklan serta berinteraksi dengan pelanggan (Wang S. F., 2011). Salah satu perusahaan telekomunikasi Indonesia yang menggunakan fanpage Facebook untuk melakukan pemasaran dan kegiatan iklan serta berinteraksi dengan pelanggan, adalah Smartfren. Smartfren adalah operator penyedia jasa telekomunikasi berbasis teknologi CDMA dan 4G LTE yang memiliki lisensi selular dan mobilitas terbatas (fixed wireless access). Smartfren meluncurkan layanan 4G LTE - Advanced secara komersial sekaligus menghadirkan ponsel Smartfren 4G LTE pada tahun 2015. Layanan utama yang Smartfren berikan terutama pada layanan data didukung oleh produk ponsel Smartfren yang berkualitas namun terjangkau. Smartfren, melalui anak perusahaannya, meluncurkan beragam ponsel 4G LTE di sepanjang tahun 2015 (http://www.smartfren.com/id, 2016).

Berdasarkan data sotrender.com bersama Joyintermedia pada bulan Juni 2015, Smartfren menempati urutan pertama dalam hal jumlah user (user Facebook yang 
Tabel 1. Data Penjualan Vendor Ponsel Indonesia Tahun 2015

\begin{tabular}{clcc}
\hline No. & Vendor & $\begin{array}{c}\text { Volume Penjualan (Unit } \\
\text { dalam Juta) }\end{array}$ & Pangsa Pasar (\%) \\
\hline 1 & Samsung & 7,3 & 24,8 \\
2 & Asus & 4,7 & 15,9 \\
3 & Smartfren & 3,2 & 10,8 \\
4 & Advan & 2,8 & 9,6 \\
5 & Lenovo & 1,9 & 6,5 \\
6 & Merek Lain & 95 & 32,5 \\
\hline & Total & 29,3 & 100 \\
\hline
\end{tabular}

Sumber: https://www.idc.com, 2016.

menyukai halaman fanspage) mengungguli Samsung, OPPO, Lenovo dan Sony. Namun Smartfren berada di peringkat ke-3 dalam hal penjualan unit ponsel di bawah Samsung dan Asus. Padahal ketika pelanggan terkait dengan media sosial Facebook, mereka akan terhubung dalam hubungan dan interaksi secara virtual dan semakin personal (Scoot, 2009:245) hingga menimbulkan pengalaman emosional yang tinggi, dimana semakin tinggi aspek nilai fungsional, emosional dan sosial yang muncul di dalam interaksi pengalaman pelanggan dengan merek, maka pengalaman yang dirasakan oleh pelanggan akan membuat rasa puas sehingga dapat membangun hubungan yang kuat dalam hal loyalitas.

Identifikasi pelanggan dengan Smartfren didasarkan pada persepsi tentang bagaimana mereka dapat mendefinisikan perusahaan atau identitas yang dirasakan pelanggan (Dutton, Dukerich, Harquail, 1994). Komunitas fanpage Facebook dapat membantu menciptakan identitas yang mampu memicu identifikasi pelanggan. Pelanggan ingin bergabung dengan fanpage Facebook untuk memenuhi kebutuhan mereka agar diidentifikasi oleh perusahaan terkait dalam hal ini Smartfren (Schembri, S., Merrilees, B. dan Kristiansen, S., 2010).
Pengguna fanpage merek pada Facebook dapat berbagi antusias mereka tentang merek pada halaman-halaman yang disediakan dan bersatu dengan kepentingan bersama pada merek terkait (De Vries, Gensler dan Leeflang, 2012). Pelanggan yang menjadi fans dari komunitas fanpage merek perusahaan cenderung loyal, berkomitmen dan lebih terbuka untuk menerima informasi tentang merek (Bagozzi dan Dholakia, 2006). Untuk dapat bertahan di tengah maraknya persaingan, sudah selayaknya Smartfren perlu untuk lebih memperhatikan nilai pelanggan dan identifikasi merek serta dapat memprioritaskan kepuasan bagi pelanggannya karena pelanggan yang sudah puas bisa saja menjadi pelanggan yang loyal.

Penelitian ini merupakan modifikasi dari penelitian yang dilakukan oleh Deng, Z., Lu, Y., Wei, K. K., dan Zhang, J. (2010), He et al.(2012) dan Yeh, C.-H., Wang, Y.-S., dan Yieh, K. (2016). Penelitian yang dilakukan oleh Z. Deng et al. (2010) menunjukkan bahwa kepuasan berpengaruh terhadap loyalitas, nilai fungsional dan nilai emosional berpengaruh signifikan terhadap kepuasan pelanggan, sedangkan nilai sosial tidak berpengaruh terhadap kepuasan pelanggan. Kemudian kepuasan pelanggan memediasi penuh nilai fungsional dan nilai emosional 
terhadap loyalitas. Penelitian yang dilakukan oleh oleh He et al. (2012) menunjukkan bahwa identifikasi merek berpengaruh positif terhadap kepuasan pelanggan dan kepuasan pelanggan berpengaruh positif terhadap loyalitas merek. Penelitian yang dilakukan oleh oleh C.-H Yeh et al. (2016) menunjukkan bahwa nilai fungsional, nilai emosional, nilai sosial dan identifikasi merek berpengaruh positif terhadap loyalitas merek. Berdasarkan permasalahan dan teori tersebut, penulis tertarik melakukan penelitian dengan tujuan menguji pengaruh dimensi dari nilai pelanggan dan identifikasi merek terhadap loyalitas merek dengan kepuasan pelanggan sebagai variabel mediasi.

\section{METODE}

Berdasarkan tujuan yang hendak ingin dicapai, penelitian ini termasuk ke dalam penelitian deskriptif korelatif dengan pendekatan kuantitatif, yaitu sebuah hubungan penelitian yang menggambarkan karakteristik dari suatu populasi atau suatu fenomena, di mana antar variabel yang diteliti diuji keterkaitannya dengan menganalisis angka-angka hasil penelitian. Penelitian deskriptif mencoba untuk menentukan jawaban dari pertanyaanpertanyaan siapa, apa, kapan, di mana dan bagaimana. Metode yang digunakan dalam penelitian ini adalah metode survei, yakni penelitian yang mengambil sampel dari suatu populasi dan menggunakan kuesioner sebagai instrumen pengumpulan data karena variabel penelitian ini diperoleh dalam kurun waktu bersamaan. Kerangka pemikiran dalam penelitian tertuang dalam Gambar 1 yang merupakan modifikasi dari model penelitian Yeh et al. (2016), He, et al. (2012) dan Z. Deng, et al. (2010).

Berdasarkan dugaan sementara bahwa nilai fungsional berpengaruh positif terhadap

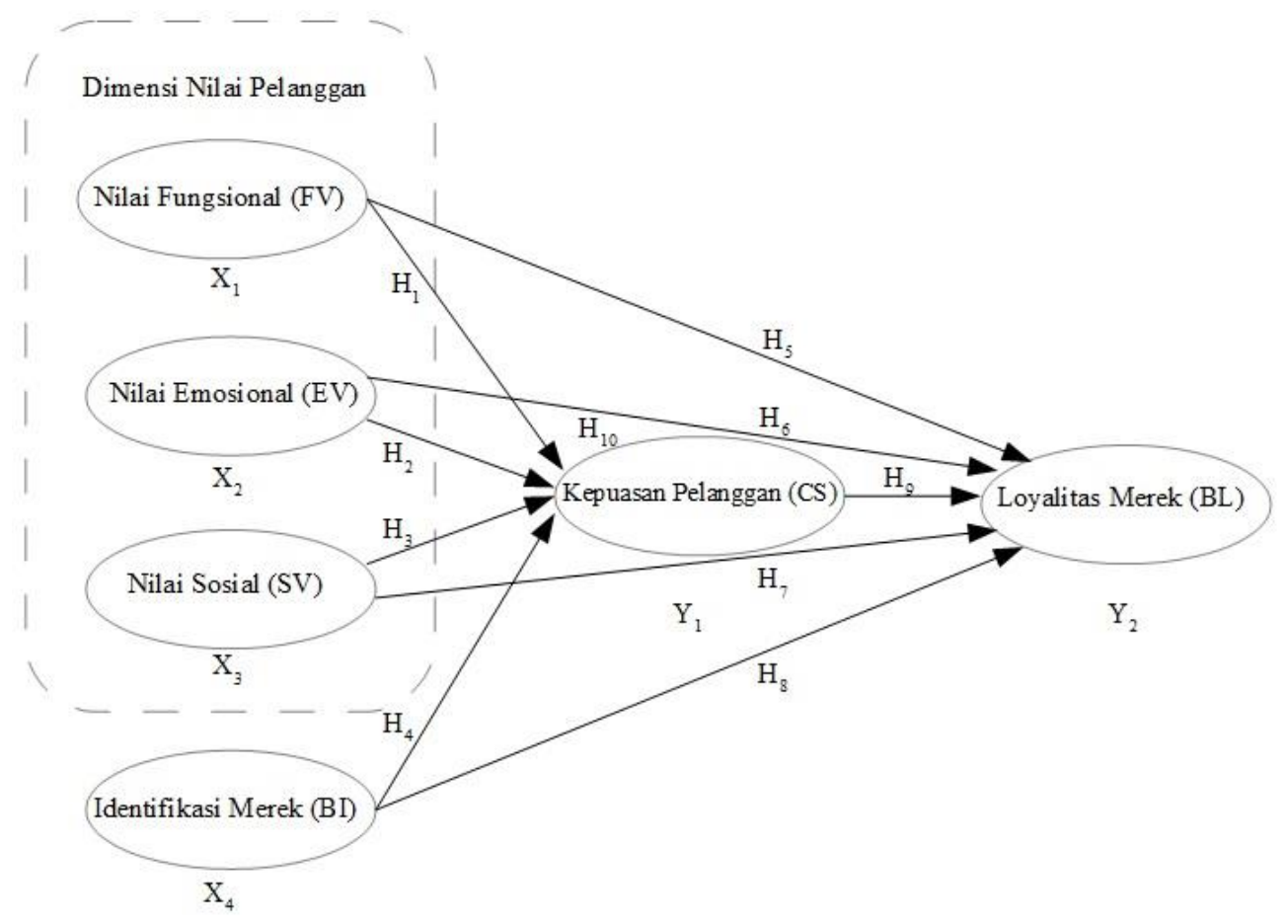

Gambar 1. Kerangka Penelitian 
kepuasan pelanggan; nilai emosional berpengaruh positif terhadap kepuasan pelanggan; nilai sosial berpengaruh positif terhadap kepuasan pelanggan; identifikasi merek berpengaruh positif terhadap kepuasan pelanggan; nilai fungsional berpengaruh positif terhadap loyalitas merek; nilai emosional berpengaruh positif terhadap loyalitas merek; nilai sosial berpengaruh positif terhadap loyalitas merek; identifikasi merek berpengaruh positif terhadap loyalitas merek; kepuasan pelanggan berpengaruh positif terhadap loyalitas merek; dan nilai fungsional, nilai emosional, nilai sosial dan identifikasi merek secara simultan berpengaruh terhadap loyalitas merek dengan dimediasi kepuasan pelanggan, maka hipotesis yang diajukan dalam penelitian ini yaitu:

$\mathbf{H}_{\mathbf{1}}=$ Nilai fungsional berpengaruh positif terhadap kepuasan pelanggan.

$\mathbf{H}_{\mathbf{2}}=$ Nilai emosional berpengaruh positif terhadap kepuasan pelanggan.

$\mathbf{H}_{\mathbf{3}}=$ Nilai sosial berpengaruh positif terhadap kepuasan pelanggan.

$\mathbf{H}_{\mathbf{4}}=$ Identifikasi merek berpengaruh positif terhadap kepuasan pelanggan.

$\mathbf{H}_{\mathbf{5}}=$ Nilai fungsional berpengaruh positif terhadap loyalitas merek.

$\mathbf{H}_{6}=$ Nilai emosional berpengaruh positif terhadap loyalitas merek.

$\mathbf{H}_{\mathbf{7}}=$ Nilai sosial berpengaruh positif terhadap loyalitas merek.

$\mathbf{H}_{\mathbf{8}}=$ Identifikasi merek berpengaruh positif terhadap loyalitas merek.

$\mathbf{H}_{\mathbf{9}}=$ Kepuasan pelanggan berpengaruh positif terhadap loyalitas merek.

$\mathbf{H}_{10}=$ Nilai fungsional, nilai emosional, nilai sosial dan identifikasi merek secara simultan berpengaruh signifikan terhadap loyalitas merek dengan kepuasan pelanggan sebagai variabel mediasi.

Ada pun yang menjadi populasi pada penelitian ini adalah seluruh user Facebook yang menyukai fanpage Smartfren yaitu sebanyak 2.796.079 user (per tanggal 7 April 2016). Sampel yang diambil adalah individu dengan karakteristik yang sama yaitu pelanggan Smartfren yang diprediksi sebagai pelanggan yang loyal pada merek Smartfren dengan memiliki dan menggunakan ponsel Smartfren serta menyukai halaman fanpage Facebook Smartfren dan minimal melakukan 2 kali aktivitas like/share/comment pada halaman fanpage Smartfren. Menurut Petrovcic, Petric dan Manfreda (2016), banyaknya jumlah aktivitas user sebanyak 210 kali pada komunitas online paling banyak menghasilkan online response rates yang tinggi yaitu sebesar $31,75 \%$. Pengumpulan data dilakukan dengan cara memberikan kuesioner online Google Docs yang dikirimkan melalui aplikasi Facebook Messenger kepada responden yang dipilih dengan kriteria di atas.

Uji instrumen penelitian meliputi uji validitas dan uji reliabilitas. Uji validitas menggunakan teknik Confirmatory Factor Analysis (CFA) dengan bantuan SPSS versi 16 . Setiap item factor pertanyaan harus memiliki nilai Kaiser-Meyer-Olkin Measure of Sampling Adequacy (KMO-MSA) > 0,50. Item pertanyaan dikatakan valid jika memiliki factor loading $\geq 0,50$ dan telah terekstrak sempurna (Ghozali, 2006). Untuk mengukur reliabilitas, peneliti menggunakan alat ukur Cronbach Alpha. Hasil pengujian hipotesis menggunakan regresi path analysis. 
Tabel 2. Hasil Uji Regresi

\begin{tabular}{|c|c|c|c|c|c|c|c|}
\hline Persamaan Pertama & $a$ & $\beta$ & error & $t$ & Sig. & $F$ & $\begin{array}{c}\text { Adjusted } \\
\text { R Square } \\
\left(R^{2}\right)\end{array}$ \\
\hline $\begin{array}{l}\text { Nilai Fungsional } \\
\text { (FV) }\end{array}$ & & 0.351 & 0,074 & 4,745 & 0,000 & & \\
\hline $\begin{array}{l}\text { Nilai Emosional } \\
\text { (EV) }\end{array}$ & & 0,077 & 0,057 & 1,351 & 0,178 & & \\
\hline $\begin{array}{l}\text { Nilai Sosial } \\
\text { (SV) }\end{array}$ & 0,520 & 0,02 & 0,088 & 0,027 & 0.979 & 27,433 & 0,378 \\
\hline $\begin{array}{l}\text { Identifikasi Merek } \\
\text { (BI) }\end{array}$ & & 0,403 & 0,085 & 4,735 & 0,000 & & \\
\hline Persamaan Kedua & $a$ & $\beta$ & error & $t$ & Sig. & $\mathrm{F}$ & $\begin{array}{l}\text { Adjusted } R \\
\text { Square }\left(R^{2}\right)\end{array}$ \\
\hline $\begin{array}{l}\text { Nilai Fungsional } \\
\text { (FV) }\end{array}$ & & 0,131 & 0,169 & 0,774 & 0,440 & & \\
\hline $\begin{array}{l}\text { Nilai Emosional } \\
\text { (EV) }\end{array}$ & & 0,133 & 0,124 & 1,075 & 0,284 & & \\
\hline $\begin{array}{l}\text { Nilai Sosial } \\
\text { (SV) }\end{array}$ & 2,743 & 0,538 & 0,190 & 2,829 & 0,005 & 12,796 & 0,253 \\
\hline $\begin{array}{l}\text { Identifikasi Merek } \\
\text { (BI) }\end{array}$ & & 0,272 & 0,195 & 1,394 & 0,165 & & \\
\hline $\begin{array}{l}\text { Kepuasan Pelanggan } \\
\text { (CS) }\end{array}$ & & 0,442 & 0,165 & 2,682 & 0,008 & & \\
\hline
\end{tabular}

\section{HASIL DAN PEMBAHASAN}

Penelitian ini menggunakan variabel bebas adalah sebagai berikut: nilai fungsional (FV), nilai emosional (EV) dan nilai sosial (SV) sebagai variabel dari dimensi nilai pelanggan dan identifikasi merek (BI). Variabel terikatnya adalah loyalitas merek (BL) dan variabel mediasinya adalah kepuasan pelanggan (CS). Operasional variabel berikut dibuat berdasarkan modifikasi kuesioner jurnal penelitian acuan dari Z., Deng, et al. (2010) dan Yeh et al. (2016). Hasil uji hipotesis dari 10 hipotesis yang diajukan dalam penelitian ini terangkum secara ringkas dalam Tabel 2.

Nilai Adjusted $R$ Square $\left(R^{2}\right)$ pada persamaan pertama Tabel 2 menunjukkan nilai 0,378 , artinya bahwa $37,8 \%$ variabel kepuasan pelanggan dapat dijelaskan oleh variabel nilai fungsional, nilai emosional, nilai sosial dan identifikasi merek. Sisanya yaitu sebesar $62,2 \%$ dijelaskan oleh variabel lain yang tidak dimasukkan dalam model penelitian ini. Persamaan regresi pertama dapat dituliskan sebagai berikut: Kepuasan Pelanggan $=0,520+0,351$ Nilai Fungsional + 0,077 Nilai Emosional $+0,02$ Nilai Sosial + 0,403 Identifikasi Merek.

Nilai Adjusted $R$ Square $\left(R^{2}\right)$ pada persamaan kedua Tabel 2 menunjukkan nilai 0,253 , artinya bahwa $25,3 \%$ variabel loyalitas merek dapat dijelaskan oleh variabel nilai fungsional, nilai emosional, nilai sosial, identifikasi merek dan kepuasan pelanggan. 
Sisanya yaitu sebesar $74,7 \%$ dijelaskan oleh variabel lain yang tidak dimasukkan dalam model penelitian ini. Persamaan regresi kedua dapat dituliskan sebagai berikut: Loyalitas Merek $=2,743+0,131$ Nilai Fungsional $+0,133$ Nilai Emosional $+0,538$ Nilai Sosial + 0,272 Identifikasi Merek + 0,442 Kepuasan Pelanggan. Berdasarkan Tabel 2 didapatkan hasil pembahasan uji hipotesis.

\section{Pengaruh nilai fungsional terhadap kepuasan pelanggan.}

Hasil uji hipotesis yang telah dilakukan menunjukkan bahwa nilai fungsional secara signifikan berpengaruh positif pada kepuasan pelanggan. Hasil uji hipotesis ini mendukung hasil penelitian terdahulu yang dilakukan oleh Fornell et al. (1996), Bojanic (1996) dan Deng et al. (2010) yang menyatakan bahwa nilai fungsional memiliki pengaruh signifikan terhadap kepuasan pelanggan. Hasil tersebut menjelaskan bahwa nilai fungsional yang berkaitan dengan manfaat praktis atau manfaat teknis yang diberikan oleh ponsel Smartfren dapat diterima oleh penggunanya dan akan meningkatkan kepuasan pelanggan Smartfren. Berbagai jenis fungsi yang ada pada ponsel Smartfren seperti kualitas ponsel, kelengkapan fitur hardware dan software, mengirim pesan, telepon, browsing internet, memainkan games, ketersediaan koneksi data yang lancar dan menjalankan aplikasi dapat dilakukan oleh pengguna ponsel Smartfren kapan saja dan dimana saja. Hal ini membuat pelanggan menjadi puas dengan nilai fungsional dari penggunaan ponsel Smartfren.

\section{Pengaruh nilai emosional terhadap kepuasan pelanggan.}

Hasil uji hipotesis yang telah dilakukan menunjukkan bahwa nilai emosional tidak memiliki pengaruh baik positif maupun negatif terhadap kepuasan pelanggan. Hasil uji hipotesis ini berbeda dengan hasil penelitian sebelumnya yang telah dilakukan oleh Deng et al. (2010) dan Butz dan Goodstein (1996) yang menyatakan bahwa nilai emosional memiliki pengaruh signifikan terhadap kepuasan pelanggan. Penggunaan ponsel Smartfren berkaitan dengan alasan fungsional bagi pelanggan Smartfren, namun hal ini tidak berpengaruh terhadap kepuasan yang dirasakan oleh mereka. Nilai emosional yang terbentuk dari pengalaman penggunaan ponsel Smartfren tidak mampu menjadikannya sebagai nilai tambah yang berkaitan dengan kepuasan pelanggan. Pada studi kasus pelanggan ponsel Smartfren ini, evaluasi keseluruhan atas penggunaan ponsel berdasarkan stimulasi emosional tidak mampu menggambarkan interpretasi perilaku pelanggan berkaitan dengan kepuasan. Tidak ada ikatan emosional pelanggan dengan merek ponsel Smartfren setelah pengalaman penggunaan produk berpengaruh terhadap aktivitas pelanggan yang menunjukkan kepuasan, karena pelanggan puas terhadap ponsel Smartfren berkaitan dengan functional benefit-nya seperti standar kualitas yang baik, performa andal dan harga yang terjangkau.

\section{Pengaruh nilai sosial terhadap kepuasan pelanggan.}

Hasil uji hipotesis yang telah dilakukan menunjukkan bahwa nilai sosial tidak memiliki pengaruh baik positif maupun 
negatif terhadap kepuasan pelanggan. Hasil uji hipotesis ini berbeda dengan penelitian sebelumnya yang dilakukan oleh Butz dart Goodstein (1996) yang menyatakan bahwa nilai emosional dapat berpengaruh terhadap kepuasan pelanggan. Namun hasil uji hipotesis ini mendukung hasil penelitian yang dilakukan oleh Deng et al. (2010) yang menyatakan bahwa nilai sosial tidak memiliki pengaruh signifikan terhadap kepuasan pelanggan. Hal tersebut menjelaskan bahwa utilitas dari penggunaan ponsel Smartfren tidak mampu menggambarkan keterkaitan antara aktivitas peningkatan pencitraan status sosial dengan kepuasan pelanggannya, hal ini terkait ponsel Smartfren termasuk kategori middle-low. Pengguna ponsel Smartfren yang mayoritas anak muda dengan persentase 38,29\% berusia kurang dari 20 tahun diprediksi bahwa aktivitas mereka yang ingin lebih dihargai dan memudahkan pergaulan pada sesama pengguna Smartfren tidak terpengaruh dengan pilihan mereka menggunakan ponsel Smartfren adalah keputusan yang tepat. Utilitas yang dihasilkan oleh persepsi pelanggan terhadap kemampuan ponsel Smartfren untuk memperkuat kehidupan sosial pelanggan tidak berkaitan dengan interpretasi perilaku kepuasan pelanggan. Pada keadaan tertentu, pelanggan Smartfren menggunakan ponsel merek Smartfren sesuai dengan referensi kelompok mereka (dalam hal ini bisa dicontohkan menjadi bagian dari fanpage Smartfren). Sangat mudah untuk mengikuti atau untuk menyesuaikan diri dengan perilaku online di mana pengaruh kelompok sosial dan nilai referensi tidak berpengaruh terhadap kepuasan yang ditimbulkan. Pada studi kasus pelanggan Smartfren ini, pelanggan diduga memiliki kebanggaan dan keyakinan bahwa orang lain kagum terhadap dia bila menggunakan produk Smartfren tidak saling berkaitan. Kepuasan yang diperoleh bukan berasal dari nilai sosial atau self-esteem yang membuat pelanggan menjadi puas terhadap merek Smartfren, tetapi berasal dari nilai fungsional.

\section{Pengaruh identifikasi merek terhadap kepuasan pelanggan.}

Hasil uji hipotesis yang telah dilakukan menunjukkan bahwa identifikasi merek secara signifikan berpengaruh positif pada kepuasan pelanggan. Hasil uji hipotesis ini mendukung hasil penelitian yang telah dilakukan oleh $\mathrm{He}$ et al. (2012) yang menyatakan bahwa identifikasi merek memiliki pengaruh signifikan terhadap kepuasan pelanggan. Hasil tersebut menjelaskan bahwa pelanggan akan selalu memiliki ponsel Smartfren yang sangat berarti bagi dirinya (terkait dengan fungsional produk) karena secara keseluruhan mereka puas dengan ponsel Smartfren. Pengaruh positif dari identifikasi merek pada kepuasan pelanggan ini lebih didukung oleh teori expectationdisconfirmation kepuasan pelanggan (Oliver, 1999). Menurut teori ini, pelanggan bisa menjadi puas ketika kinerja merek yang sesungguhnya memenuhi harapan sebelum melakukan pembelian, konsumsi, atau penggunaan (Yi dan La, 2004). Ketika harapan dari kinerja fungsional merek terpenuhi, pelanggan yang diidentifikasi oleh merek merasa lebih puas. 


\section{Pengaruh nilai fungsional terhadap} loyalitas merek.

Hasil uji hipotesis yang telah dilakukan menunjukkan bahwa nilai fungsional tidak memiliki pengaruh baik positif maupun negatif terhadap loyalitas merek. Hasil uji hipotesis ini berbeda dengan hasil penelitian sebelumnya yang telah dilakukan oleh Yeh et al. (2016) yang menyatakan bahwa nilai fungsional memiliki pengaruh signifikan terhadap loyalitas merek. Pengguna ponsel Smartfren merasa bahwa produk yang mereka gunakan tersebut dapat memenuhi kebutuhan fungsional akan sebuah ponsel dan dapat diandalkan. Namun berdasarkan data koresponden yang menyebutkan bahwa mayoritas koresponden juga memiliki ponsel merek lain selain Smartfren (61,71\%) maka tidak dapat dikatakan bahwa pengguna ponsel Smartfren tersebut loyal terhadap merek Smartfren. Koresponden diduga memilih menggunakan ponsel Smartfren sebagai pilihan kedua sehingga diduga pula pengguna lebih menunjukkan loyalitasnya terhadap ponsel merek lain yang dimilikinya. Secara fungsional, pelanggan menggunakan ponsel merek Smartfren untuk memenuhi kebutuhan komunikasi dan hiburan. Pada nilai fungsional ini, pelanggan lebih mempertimbangkan fungsi seperti harga, kualitas, kelengkapan fitur komunikasi, media sosial dan hiburan yang disediakan dan variasi jenis produk yang beragam sehingga dapat menemukan produk yang dibutuhkan. Pengguna ponsel Smartfren diduga masih pada tingkatan switcher buyer yaitu pembeli yang berada di tingkatan paling dasar karena tingkat keseringan pembeli untuk berpindah merek ke merek yang lainnya dengan pertimbangan banyak faktor, misalnya harga yang bersaing dan fitur yang kekinian pada ponsel merek kompetitor.

\section{Pengaruh nilai emosional terhadap loyalitas merek.}

Hasil uji hipotesis yang telah dilakukan menunjukkan bahwa nilai emosional tidak memiliki pengaruh baik positif maupun negatif terhadap loyalitas merek. Hasil uji hipotesis ini berbeda dengan hasil penelitian sebelumnya yang telah dilakukan oleh Yeh et al. (2016) yang menyatakan bahwa nilai emosional memiliki pengaruh signifikan terhadap loyalitas merek. Hal ini bisa terjadi karena walaupun pengguna ponsel Smartfren menyukai dan merasa bangga dengan produk yang digunakannya tersebut, tetapi tidak menunjukkan bahwa mereka juga pelanggan yang loyal dengan merek Smartfren. Hal ini terbukti dengan mayoritas koresponden (61,71\%) memiliki ponsel merek lain selain Smartfren. Atribut-atribut dari nilai emosional dalam penelitian ini yaitu kemampuan ponsel Smartfren menimbulkan perasaan suka, senang dan bangga serta menciptakan ketertarikan bagi penggunanya tidak menggambarkan interpretasi perilaku pelanggan berkaitan dengan loyalitas merek. Tidak ada ikatan emosional pelanggan dengan merek ponsel Smartfren setelah pengalaman penggunaan produk berpengaruh terhadap aktivitas pelanggan yang menunjukkan loyalitas seperti: pelanggan berkomentar yang baik, menyukai atau membagikan tautan status yang diunggah admin di fanpage Smartfren. 


\section{Pengaruh nilai sosial terhadap loyalitas merek.}

Hasil uji hipotesis yang telah dilakukan menunjukkan bahwa nilai sosial memiliki pengaruh positif terhadap loyalitas merek. Hasil uji hipotesis ini mendukung hasil penelitian yang telah dilakukan sebelumnya oleh Yeh et al. (2016) yang menyatakan bahwa nilai sosial memiliki pengaruh signifikan terhadap loyalitas merek. Hal ini bisa terjadi karena pengalaman penggunaan ponsel Smartfren membantu pelanggan berinteraksi dengan yang lainnya. Ketika pelanggan merasakan nilai sosial yang lebih tinggi dari ponsel Smartfren, mereka menunjukkan perilaku loyalitas merek yang lebih besar seperti mengatakan hal yang positif dan menjadikannya pilihan pertama ketika melakukan pembelian ponsel. Selain itu, ponsel yang merupakan produk teknologi membawa arti simbolis, memungkinkan pelanggan untuk mengkomunikasikan gaya hidup dan keyakinan mereka kepada sesama pengguna, sehingga memperoleh nilai sosial. Nilai sosial mempunyai pengaruh positif terhadap loyalitas pelanggan juga karena berkaitan dengan kemampuan ponsel Smartfren untuk meningkatkan citra diri sosial pelanggan. Semakin tinggi penilaian pelanggan dari segi sosial terhadap ponsel Smartfren maka akan semakin tinggi pula loyalitas yang terjalin.

\section{Pengaruh identifikasi merek terhadap loyalitas merek.}

Hasil uji hipotesis yang telah dilakukan menunjukkan bahwa identifikasi merek tidak memiliki pengaruh baik positif maupun negatif terhadap loyalitas merek. Hasil uji hipotesis ini berbeda dengan hasil penelitian sebelumnya yang telah dilakukan oleh Yeh et al. (2016) yang menyatakan bahwa identifikasi merek memiliki pengaruh signifikan terhadap loyalitas merek. Hal ini bisa terjadi diduga karena ketika pengguna ponsel Smartfren sudah menjadi bagian dari hidup pelanggan tidak ada pengaruhnya dengan loyalitas yang ditunjukkan. Hal ini terbukti dengan mayoritas koresponden $(61,71 \%)$ memiliki ponsel merek lain selain Smartfren. Positioning yang ditonjolkan ponsel merek Smartfren seperti ponsel low entry, harga terjangkau, performa handal, fitur lengkap tidak mampu menunjukkan pengaruh terhadap aktivitas pelanggan yang berkaitan dengan loyalitas merek sehingga masih rentan menjadikan pelanggan ponsel merek Smartfren beralih ke merek kompetitor.

\section{Pengaruh kepuasan pelanggan terhadap loyalitas merek.}

Hasil uji hipotesis yang telah dilakukan menunjukkan bahwa kepuasan pelanggan secara signifikan berpengaruh positif pada loyalitas merek. Hasil uji hipotesis ini mendukung hasil penelitian yang telah dilakukan sebelumnya oleh Deng et al. (2010) dan He et al.(2012) yang menyatakan bahwa kepuasan pelanggan memiliki pengaruh signifikan terhadap loyalitas merek. Jika pelanggan memiliki pengalaman penggunaan ponsel Smartfren yang baik, maka ia akan memiliki kepuasan yang kumulatif. Pelanggan yang puas akan memiliki tingkat penggunaan yang tinggi dari ponsel Smartfren daripada mereka yang tidak puas, dan mereka lebih mungkin untuk memiliki niat kuat dan secara terus-menerus untuk merekomendasikan Smartfren kepada 
teman-teman mereka atau kerabat (Zeithaml, et al., 1996). Jika Smartfren dapat memenuhi kebutuhan pelanggan yang lebih baik dibandingkan pesaingnya, maka akan lebih mudah untuk menciptakan loyalitas (Oliver, 1999). Fornell (1996) menyatakan bahwa loyalitas pelanggan yang tinggi terutama disebabkan oleh kepuasan pelanggan yang tinggi. Clarke (2001) mengusulkan bahwa kepuasan yang efektif harus mampu menciptakan loyalitas di antara pelanggan.

\section{Pengaruh nilai fungsional, nilai emosional, nilai sosial dan identifikasi merek secara simultan terhadap loyalitas merek dengan dimediasi oleh kepuasan pelanggan.}

Hasil uji hipotesis yang telah dilakukan menunjukkan bahwa nilai fungsional, nilai emosional, nilai sosial dan identifikasi merek secara simultan tidak berpengaruh terhadap loyalitas merek dengan dimediasi oleh kepuasan pelanggan. Hasil uji hipotesis ini berbeda dengan hasil penelitian sebelumnya yang telah dilakukan oleh Caruana (2002) dan Heung dan Ngai (2008) yang menyatakan bahwa kepuasan pelanggan dapat berpengaruh memediasi semua faktor-faktor terhadap loyalitas merek.

Berdasarkan hasil uji hipotesis dapat diketahui bahwa kepuasan pelanggan tidak mampu memberikan pengaruh mediasi hubungan antara nilai fungsional terhadap loyalitas merek. Artinya ketika pelanggan menggunakan ponsel Smartfren yang memiliki nilai fungsional tinggi maupun rendah tidak akan berpengaruh loyalitas mereka terhadap merek ponsel Smartfren dengan dimediasi kepuasan. Koresponden diduga memilih menggunakan ponsel
Smartfren sebagai pilihan kedua sehingga diduga pula pengguna lebih menunjukkan loyalitasnya terhadap ponsel merek lain yang dimilikinya. Pengguna ponsel Smartfren diduga masih pada tingkatan switcher buyer yaitu pembeli yang berada di tingkatan paling dasar karena tingkat keseringan pembeli untuk berpindah merek ke merek yang lainnya dengan pertimbangan banyak faktor, misalnya harga yang bersaing dan fitur yang kekinian pada ponsel merek kompetitor.

Berdasarkan hasil uji hipotesis dapat diketahui bahwa kepuasan pelanggan tidak mampu memberikan pengaruh mediasi hubungan antara nilai emosional terhadap loyalitas merek. Artinya ketika pelanggan menggunakan ponsel Smartfren yang memiliki nilai emosional tinggi maupun rendah tidak akan berpengaruh loyalitas mereka terhadap merek ponsel Smartfren dengan dimediasi kepuasan. Penggunaan ponsel Smartfren berkaitan dengan alasan fungsional bagi pelanggan Smartfren, namun hal ini tidak berpengaruh terhadap kepuasan yang dirasakan oleh mereka. Nilai emosional yang terbentuk dari pengalaman penggunaan ponsel Smartfren tidak mampu menjadikannya sebagai nilai tambah yang berkaitan dengan kepuasan pelanggan. Tidak ada ikatan emosional pelanggan dengan merek ponsel Smartfren setelah pengalaman penggunaan produk berpengaruh terhadap aktivitas pelanggan yang menunjukkan kepuasan. Atribut-atribut dari nilai emosional dalam penelitian ini yaitu kemampuan ponsel Smartfren menimbulkan perasaan suka, senang dan bangga serta menciptakan ketertarikan bagi penggunanya juga tidak menggambarkan interpretasi perilaku pelanggan berkaitan dengan 
loyalitas merek. Tidak ada ikatan emosional pelanggan dengan merek ponsel Smartfren setelah pengalaman penggunaan produk berpengaruh terhadap aktivitas pelanggan yang menunjukkan loyalitas seperti: pelanggan berkomentar yang baik, menyukai atau membagikan tautan status yang diunggah admin di fanpage Smartfren.

Berdasarkan hasil uji hipotesis dapat diketahui bahwa kepuasan pelanggan tidak mampu memberikan pengaruh mediasi hubungan antara nilai sosial terhadap loyalitas merek. Artinya ketika pelanggan menggunakan ponsel Smartfren yang memiliki nilai sosial tinggi maupun rendah tidak akan berpengaruh loyalitas mereka terhadap merek ponsel Smartfren dengan dimediasi kepuasan. Hal tersebut menjelaskan bahwa utilitas dari penggunaan ponsel Smartfren tidak mampu menggambarkan keterkaitan antara aktivitas peningkatan pencitraan status sosial dengan kepuasan pelanggannya, hal ini terkait ponsel Smartfren termasuk kategori middlelow (http://gadget.bisnis.com, 2014). Pengguna ponsel Smartfren yang mayoritas anak muda dengan persentase $38,29 \%$ berusia kurang dari 20 tahun diprediksi bahwa aktivitas mereka yang ingin lebih dihargai dan memudahkan pergaulan pada sesama pengguna Smartfren tidak terpengaruh dengan pilihan mereka menggunakan ponsel Smartfren adalah keputusan yang tepat. Utilitas yang dihasilkan oleh persepsi pelanggan terhadap kemampuan ponsel Smartfren untuk memperkuat kehidupan sosial pelanggan tidak berkaitan dengan interpretasi perilaku kepuasan pelanggan.
Berdasarkan hasil penelitian menunjukkan bahwa identifikasi merek berpengaruh positif terhadap loyalitas merek dengan dimediasi sempurna oleh kepuasan pelanggan. Hasil tersebut menjelaskan bahwa pelanggan akan selalu memiliki ponsel Smartfren yang sangat berarti bagi dirinya (terkait dengan fungsional produk) karena secara keseluruhan mereka puas dengan ponsel Smartfren. Pelanggan bisa menjadi puas ketika kinerja merek yang sesungguhnya memenuhi harapan sebelum melakukan pembelian, konsumsi, atau penggunaan (Yi dan La, 2004). Ketika harapan dari kinerja fungsional merek terpenuhi, pelanggan yang diidentifikasi oleh merek merasa lebih puas. Penelitian ini juga menunjukkan bahwa ketika pelanggan mengidentifikasi merek produk yang mereka gunakan, mereka memiliki kecenderungan untuk membeli dan merekomendasikan produk perusahaan lebih banyak lagi. Dalam sebuah penelitian di antara komunitas merek, ditemukan bahwa pelanggan yang mengidentifikasi dengan komunitas merek juga cenderung mendukung dan membuat rekomendasi positif tentang merek tersebut (Yeh et al., 2016).

\section{SIMPULAN}

Berdasarkan analisis dan pembahasan dari rumusan masalah yang diangkat dalam penelitian ini, maka dapat disimpulkan sebagai berikut : nilai fungsional terbukti berpengaruh positif signifikan terhadap kepuasan pelanggan; nilai emosional tidak terbukti berpengaruh terhadap kepuasan pelanggan; nilai sosial tidak terbukti berpengaruh terhadap kepuasan pelanggan; identifikasi merek terbukti berpengaruh 
positif signifikan terhadap kepuasan pelanggan; nilai fungsional tidak terbukti berpengaruh terhadap loyalitas merek; nilai emosional tidak terbukti berpengaruh terhadap loyalitas merek; nilai sosial terbukti berpengaruh positif signifikan terhadap loyalitas merek; identifikasi merek tidak terbukti berpengaruh terhadap loyalitas merek; kepuasan pelanggan terbukti berpengaruh positif signifikan terhadap loyalitas merek; nilai fungsional, nilai emosional, nilai sosial dan identifikasi merek tidak terbukti berpengaruh secara simultan terhadap loyalitas merek dengan kepuasan pelanggan sebagai variabel mediasi.

Hasil penelitian ini menunjukkan bahwa nilai fungsional dan identifikasi merek berpengaruh positif terhadap kepuasan pelanggan, sehingga untuk meningkatkan kepuasan pelanggan perlu stimulus-stimulus yang berkaitan dengan nilai fungsional dan identifikasi merek. Stimulus yang berkaitan dengan nilai fungsional di antaranya adalah mempunyai standar kualitas yang dapat diterima pelanggan, performa handal dan nilai ekonomis produk. Strategi pemasaran yang dapat diimplementasikan oleh praktisi berdasarkan stimulus ini yaitu: menyampaikan secara viral standar komponen dan fitur lengkap yang dimiliki ponsel Smartfren melalui media iklan dan komunitas virtual merek serta positioning harga yang tepat sesuai segmentasi pasar agar pelanggan menjadi puas. Stimulus yang berkaitan dengan identifikasi merek di antaranya yaitu pelanggan mempunyai rasa memiliki terhadap ponsel merek Smartfren serta menggunakan ponsel merek Smartfren menjadikan diri pelanggan berarti dan menjadi bagian dari hidupnya. Stimulus- stimulus ini perlu disosialisasikan kepada pelanggan dan ditidaklanjuti oleh manajer pemasaran dalam implementasi strategi pemasaran. Strategi pemasaran yang dapat diimplementasikan oleh praktisi berdasarkan stimulus ini yaitu: memaksimalkan peran dan fungsi customer services baik di gerai offline maupun secara online oleh admin di komunitas virtual merek dengan aktif menyampaikan info produk baru, aktif interaksi terhadap keluhan pelanggan dan mengadakan quiz serta event. Kepuasan pelanggan perlu ditingkatkan karena dalam penelitian ini berpengaruh positif terhadap loyalitas merek.

Dalam penelitian ini juga diindikasikan bahwa nilai sosial berpengaruh langsung terhadap loyalitas merek, meskipun tidak berpengaruh terhadap kepuasan pelanggan. Sehingga untuk meningkatkan loyalitas merek dapat dilakukan upaya-upaya dengan meningkatkan stimulus-stimulus terkait dengan nilai sosial seperti utilitas ponsel merek Smartfren memudahkan pelanggannya dalam berinteraksi dengan pengguna lainnya, produk merek Smartfren mudah diterima oleh kelompok-kelompok sosial yang menjadikan produk ini menjadi alternatif referensi ponsel yang harus dibeli. Strategi pemasaran yang dapat diimplementasikan oleh praktisi berdasarkan stimulus ini yaitu: mengadakan event gathering sesama pengguna ponsel Smartfren disertai mengundang para blogger dan jurnalis.

Dalam penelitian ini juga diindikasikan bahwa nilai emosional dan nilai sosial tidak berpengaruh terhadap kepuasan pelanggan. Hal ini diduga karena evaluasi keseluruhan atas penggunaan ponsel berdasarkan 
stimulasi emosional dan sosial tidak mampu menggambarkan interpretasi perilaku pelanggan berkaitan dengan kepuasan. Tidak ada ikatan emosional pelanggan dengan merek ponsel Smartfren setelah pengalaman penggunaan produk berpengaruh terhadap aktivitas pelanggan yang menunjukkan kepuasan. Utilitas dari penggunaan ponsel Smartfren tidak mampu menggambarkan keterkaitan antara aktivitas peningkatan pencitraan status sosial dengan kepuasan pelanggannya, hal ini terkait ponsel Smartfren termasuk kategori middle-low. Pelanggan merasa puas terhadap ponsel Smartfren berkaitan dengan functional benefit-nya seperti standar kualitas yang baik, performa andal dan harga yang terjangkau.

Hasil penelitian ini juga mengindikasikan bahwa kepuasan pelanggan tidak memediasi pengaruh nilai fungsional, nilai emosional dan nilai sosial terhadap loyalitas merek. Hanya identifikasi merek yang diindikasikan dimediasi secara penuh oleh kepuasan pelanggan terhadap loyalitas merek. Strategi pemasaran yang dapat diimplementasikan oleh praktisi berdasarkan stimulus ini yaitu: meningkatkan pelayanan purna jual Smartfren sehingga pelanggan merasa dihargai dan menjadi bagian dari Smartfren dan selanjutnya menjadi puas dan loyal terhadap produk ponsel Smartfren. Smartfren dapat melakukan strategi meningkatkan layanan purna jual sebagai berikut: membuka gerai cabang di mall dan pusat perbelanjaan di seluruh kota-kota yang menjadi marketshare Smartfren serta layanan services gadget yang cepat dan ramah. Smartfren juga dapat aktif menjumpai pelanggannya di komunitas online seperti Facebook, Instagram dan Twitter. Smartfren juga dapat berpartisipasi aktif sponsorship di kegiatan-kegiatan komunitas terutama untuk event-event yang menjadi trending lifestyle seperti lomba lari maraton dan festival lempar bubuk warna. Stimulus - stimulus tersebut dapat menjadi informasi penting bagi pemasar merek suatu produk karena memiliki pengaruh dalam membentuk pelanggan yang loyal terhadap merek, sehingga diharapkan dapat menjadi masukan dan bahan pertimbangan yang bermanfaat bagi pemasar dalam memahami karakter pelanggan dan meningkatkan strategi pemasarannya agar mampu meningkatkan jumlah pelanggan dan pangsa pasarnya.

\section{DAFTAR PUSTAKA}

Bagozzi, R.P., Dholakia, U.M. (2006). Antecedents and Purchase Consequences of Customer Participation in Small Group Brand Communities. Int. J. Res. Mark. 23 (1), 45-61.

Bhattacharya, C. B., \& Sen, S. (2003). Consumer-Company Identification: a Framework for Understanding Consumers Relationships with Companies. Journal of Marketing. 67(2), 76-88.

Bojanic, D. (1996). Consumer Perceptions of Price, Value and Satisfaction in the Hotel Industry: an Exploratory Study. Journal of Hospitality and Leisure Marketing 4(1), 522.

Butz, H. \& Goodstein. (1996). Measuring Customer Value: Gaining the Strategic Advantage. New York: McGraw Hill.

Caruana, A. (2002). Service loyalty: The Effects of Service Quality and The Mediating Role of Customer Satisfaction. 
European Journal of Marketing. 37(7-8), 811-828.

Clarke, K. (2001). What price on loyalty when a brand switch is just a click away? Qualitative Market Research: An International Journal. 4(3), 160-168.

De Vries, L., Gensler, S., Leeflang, P.S.H. (2012). Popularity of Brand Posts on Brand Fan Pages: an Investigating of the Effects of Social Media Marketing. J. Interactive Mark. 26, 83-91.

Deng, Z., Lu, Y., Wei, K. K., \& Zhang, J. (2010). Understanding Customer Satisfaction and Loyalty: an Empirical Study of Mobile Instant Messages in China. International Journal of Information Management. 30(4), 289-300.

Dutton, J.E., Dukerich, J.M., Harquail, C.V. (1994). Organizational Images and Member Identification. Adm. Sci. Q. 39, 239-263.

Fornell, C. (1996). The American Customer Satiafaction Index: Nature, Purpose, and Findings. Journal of Marketing 60, 7-18.

Hansen, J. D., Beitelspacher, L. S., \& Deitz, G. D. (2013). Antecedents and Consequences of Consumers Comparative Value Assessments Across the Relationship Life Cycle. Journal of Business Research. 66(4), 473-479.

He, H., Li, Y., \& Harris, L. (2012). Social Identity Perspective on Brand Loyalty. Journal of Business Research. 65(5), 648657.

Heung, V. C. S., \& Ngai, E. W. T. (2008). The mediating effects of perceived value and customer satisfaction on customer loyalty in the Chinese restaurant setting. Journal of Quality Assurance in Hospitality \& Tourism. 9(2), 85-107.

http://gadget.bisnis.com/read/20140827/28 0/253021/smartfren-fokus-bidik- segmen-bawah (diakses pada 25 Juli 2016; Pkl. 00.44 WIB)

http://www.smartfren.com/id (diakses pada 3 Februari 2016; Pkl. 07.44 WIB)

https://www.idc.com/getdoc.jsp?containerl $\mathrm{d}=$ prAP41041116 (diakses pada 3 Februari 2016; PkI. 07.54 WIB)

Huseni, Umar, 2000. Riset Pemasaran dan Perilaku Konsumen. Jakarta: Erlangga.

Jones, T. O., \& Sasser, W. E. (1995). Why Satisfied Customers Defect?. Harvard Business Review. 73(6), 88-99.

Karjaluoto, H., Jayawardhena, C., Leppaniemi, M., \& Pihlstrom, M. (2012). How Value and Trust Influence Loyalty in Wireless Telecommunications Industry. Telecommunications Policy. 36(8), 636649.

Kim, H. W., Gupta, S., \& Koh, J. (2011). Investigating the Intention to Purchase Digital Items in Social Networking Communities: A Customer Value Perspective. Information \& Management. 48(6), 228-234.

Oliver, R. L. (1999). Whence Consumer Loyalty?. Journal of Marketing. 63(4), 3344.

Petrovčič, A., Petrič, G., \& Manfreda, K. L. (2016). The effect of email invitation elements on response rate in a web survey within an online community. Computers in Human Behavior, 56, 320-329.

Schembri, S., Merrilees, B., Kristiansen, S. (2010). Brand Consumption and Narrative of The Self. Psychol. Mark. 27 (6), 623-637.

Scoot, David Meerman. (2009). The New Rules of Marketing and PR. New Jersey: John Wiley and Sons, Inc.

Stokburger-Sauer, N., Ratneshwar, S., \& Sen, S. (2012). Drivers of Consumer-Brand 
Identification. International Journal of Research in Marketing. 29(4), 406-418.

Sweeney, J. C., \& Soutar, G. N. (2001). Consumer Perceived Value: The Development of A Multiple Item Scale. Journal of Retailing. 77(2), 203-220.

Tu`skej, U., Golob, U., \& Podnar, K. (2013). The Role of Consumer-Brand Identification in Building Brand Relationships. Journal of Business Research. 66(1), 53-59.

Wang, S. F. (2011). Development trends of global Internet community. Taipei, TW: The Ministry of Economy ITIS Plan.
Yeh, C.-H., Wang, Y.-S., \& Yieh, K. (2016). Predicting Smartphone Brand Loyalty: Consumer Value and Consumer Brand Identification Perspectives. International Journal of Information Management. 36, 245-257.

Yi, Y., \& La, S. (2004). What influences the relationship between customer satisfaction and repurchase intention? Investigating the effects of adjusted expectations and customer loyalty. Psychology \& Marketing. 21(5), 351-374.

Zeithaml, V. A., Berry, L. L., \& Parasuraman, A. (1996). The Behavioral Consequences of Service Quality. Journal of Marketing. 60(2), 31-46. 